\title{
Iceland's external affairs from the Napoleonic era to the occupation of Denmark: Danish and British shelter
}

\author{
Baldur Thorhallsson, Professor of Political Science, University of Iceland \\ Tómas Joensen, Researcher, University of Iceland
}

\begin{abstract}
This paper argues that Iceland enjoyed essential shelter, for its development and prosperity, provided by Denmark and Britain. Societal relations with Copenhagen were of fundamental importance in the preservation and evolution of Icelandic identity and culture, providing the foundation of the modern society and leading to the establishment of the Icelandic state. Danish financial backups created the basis for the island's economic prosperity in the 20th century. Moreover, Denmark provided partial political shelter in terms of significant diplomatic support in guaranteeing trade agreements with other states. Also, Denmark led by example and Iceland followed its foreign policy. On the other hand, Denmark failed to provide Iceland with protection of its land and waters and economic cover when it was in most need. Moreover, the economic cover it did provide was, at times, highly costly. Denmark had been downgraded to a small European power in the post-Napoleonic period. In practice, Britain was in control over the North Atlantic. It guaranteed Iceland's neutrality and connection to the outside world and markets when the Danish authorities failed in these areas, as long as British interests were also served. Nor did British protection come without cost. Accordingly, this paper confirms the common claim of small-state studies that small states are at the mercy of their larger neighbours. Moreover, our findings indicate that Iceland's growing autonomy did not affect its need for political, economic and societal cover.
\end{abstract}

Keywords: Iceland; small states; shelter; Denmark; Britain.

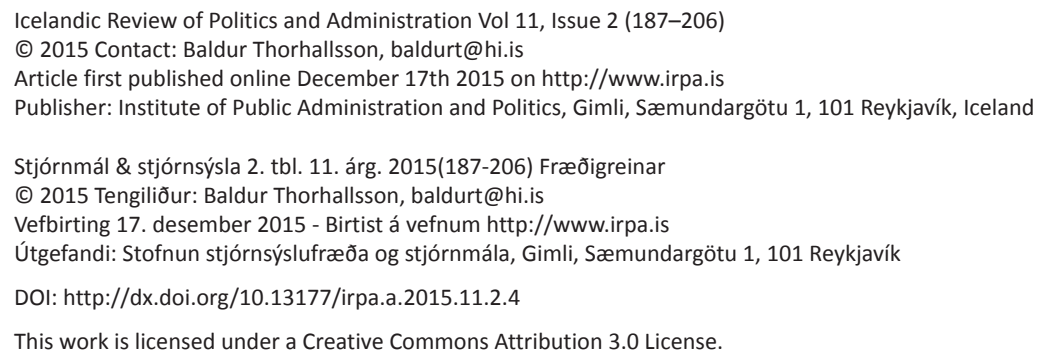




\section{Introduction}

This paper is the fourth in a 'hexalogy' (a series of six) that examines Iceland's foreign relations from the time of Settlement to the present day. It will cover part of the 'Danish period' from 1815, at the end of the Napoleonic wars, until 1940 when Danish-Icelandic relations were severed by the German occupation of Denmark. The previous three papers have examined 'the Norwegian Period' (from the Settlement to 1400), 'the English and German Periods' (from c. 1400 to the Reformation in the mid-16 ${ }^{\text {th }}$ century) and the first part of the 'Danish Period' until the end of the Napoleonic era (see Pórhallsson 2012; Dórhallsson \& Kristinsson 2013; Pórhallsson \& Joensen 2014).

These studies build on an assumption from the International Relations literature that small states/entities are uniquely vulnerable, economically and politically. They cannot defend themselves and the smallness of their domestic markets makes them reliant on access to larger markets in order to flourish. This makes small states more vulnerable to external, as well as internal, shocks, as there are few domestic buffers that can absorb the burden of economic and political shocks (Katzenstein 1984).

The assumption has been taken further by the shelter theory which claims that small states/entities need political, economic and societal shelter provided by their larger neighbours and/or international organizations in order to prosper, domestically, and thrive in the international system (Thorhallsson 2011). The aim of these studies is to examine whether the expectations of shelter theory address the reality of Iceland's external relations through history. Also, the papers make an attempt to test shelter theory on the case of Iceland - an entity which developed from being a peripheral outpost in Europe to a modern state at the centre of attention by superpowers in the post-WWII period.

The previous papers lay out how the shelter theory can be applied to a sovereign small state in the international system and small peripheral entities within a state (the periphery and the core). The case of Iceland fits perfectly into the picture of a vulnerable small dependency, and Rokkan and Urwin's (1983) three types of transitions which construct the centre-periphery relations model in how the periphery is dependent upon the centre, i.e. concerning economy, politics and culture. Moreover, their three key characteristics of peripheries which distinguish them from the centre (distance, difference and dependence) place Icelandic-Danish relations in a new light. Furthermore, shelter theory has, for instance, been used to analyze the shelter options available to Scotland and the costs and benefits of staying in a union with the UK or becoming independent (Bailes, Thorhallsson \& Johnstone 2013). As the current study and previous studies show, Iceland sought shelter in non-Danish actors against the wishes of Denmark. Therefore, Iceland is an entity that seeks benefits from Denmark but when it cannot get those benefits, it seeks them from other actors that can provide them. Hence, Iceland's relations with Denmark is one of benefits and costs for both actors, it was not just the Danish exploitation of Iceland as the traditional historical narrative claims.

The shelter theory mainly addresses three interrelated issues: reduction of risk before a possible crisis event, assistance in absorbing shocks when risk goes bad and help in 
cleaning up after the event. There are three categories of shelter: economic, political and societal. Economic shelter may take the form of direct economic assistance, help from an external financial authority, a common market, favourable market access, etc. Political shelter consists of direct and visible diplomatic or military backing by other states or international organizations. Also, political shelter can be in the form of beneficial norms and rules of the international system for small entities/states (Thorhallsson 2011).

The consideration of societal shelter is based on Rokkan and Urwin's (1983) account of the importance of centre-periphery relationships in state-building in Western Europe. Societal shelter refers to transfers of messages, norms, lifestyles, ideologies, myths and ritual systems between the central and the peripheral nation. Cultural relationships are important in order to avoid isolation and seek acknowledgement though these relations, i.e. the significant of being part of a wider societal community and its associated benefits.

In these connections, it is important to bear in mind that shelter may involve various costs for the small state (Bailes \& Thorhallsson 2013). However, this price may never be higher than the gains it receives: otherwise one cannot refer to this as shelter. Also, one cannot claim that an act or an event stemming from foreign influences was a form of shelter if it was only beneficial for the small state's elites.

With its limited scope, this paper does not seek to trace all aspects of Iceland's external relations during this important period in its history. Instead, it will make an attempt to examine particular features of Iceland's foreign relations and place them within the shelter theory. On the other hand, in taking Iceland's external relations as a focus for tracing the country's development, it tries to escape the overwhelming emphasis on the country's quest for independence and sovereignty which dominated the historical literature for most of the $20^{\text {th }}$ century. However, as already stated, most often both costs and benefits are associated with external relations, which need to be taken into consideration.

Gradually, Icelanders requested and gained greater autonomy from the mid-19 ${ }^{\text {th }}$ century onwards. The Althingi (the national parliament) was restored in 1843; the dependency was granted a constitution in 1874 and gained home rule in 1904. It became a sovereign state under a joint monarchy in 1918 with the Danish-Icelandic Act of Union. Accordingly, the country was in full charge of most of its domestic affairs from the first years of the new century and became an independent state in full charge of its foreign affairs at the end of the First World War.

In the following sections of this paper, we will address the three elements of shelter defined in this introduction. First we will examine Iceland's economic relations in the period. The second part will focus on Iceland's political relations with Denmark and Britain and the third part deals with Iceland's cultural and social relations with the outside world. Lastly, the concluding part will summarize the main findings of the paper.

\section{Economic shelter}

This section examines whether Iceland's external relations with its neighbouring states provided economic cover in the period under study. It will thoroughly analyse a number 
of cases in order to evaluate to what extent these entailed benefits or costs for Icelandic society.

From the $18^{\text {th }}$ century onwards, expenses exceeded the profits that the Danish kingdom received from Iceland. Iceland received Danish subsidies for the bulk of the period in order to run the state. In the 1870s, the contribution of the Danish Treasury amounted to about a fifth of total income in Iceland with the transfer of fiscal powers to Iceland and a new tax system. These payments gradually decreased in line with a decision by the Danish government and were substantially less at the turn of the century - both in absolute and in relative terms (the Icelandic economy had grown while the payments had decreased; Karlsson 2009, 221). In 1905, these payments accounted for around 5 per cent of the Icelandic budget. Denmark stopped its direct payments into the Icelandic budget when Iceland became sovereign in 1918 (Júlíusson \& Ísberg 2005, 277; Karlsson 2009, 294-301). These direct payments were in line with the shelter theory's claim that protectorates are often in need of subsidies from their protectors.

The trade monopoly ended in 1787 and restrictions on who could conduct trade in Iceland were loosened. However, this did not mean that trade was entirely free, as the changes only allowed subjects of the Danish king (where monopoly trade was not practiced) to trade in Iceland. There were high tariffs in place to ensure that merchants from outside the kingdom would not be able to compete with those from inside it (Karlsson 2008, 339). Furthermore, as a result of its defeat in the Napoleonic wars, Denmark lost Norway into the hands of Sweden in the peace settlements that followed. This effectively ended Iceland's formal link with Norway which had lasted since 1262. Norway was now outside the kingdom and Norwegian merchants had to seek special licences to trade in Iceland. The island had thus lost its most important provider of timber, an essential product that could not be produced domestically. This shows how precarious it could be for Iceland to be part of a closed trading system that was shrinking and be unable to turn to sources of supply outside the kingdom for necessities (from 1821 timber imports of foreign merchants (mainly Norwegian) were exempted from import levies). Consequently, the abolition of the trade monopoly had a minuscule effect on the structure of trade in Iceland and Danish merchants continued to dominate all areas of foreign trade.

Iceland continued to demand an end to restrictions on trade with foreign nations. These demands for freedom in trading activities were related to the increased demand for freedom on the political level that had started in the first half of the $19^{\text {th }}$ century (Karlsson 2008, 339-341). Increased national sentiments were reaching all areas of society as the romantic ideology became more popular throughout the country. As a result, Danish activities and Danish influence in Iceland were increasingly seen as negative. Historically, the trade monopoly was seen as the epitome of Danish oppression in Iceland. Iceland eventually had its demands met and in 1855 trade restrictions were lifted and Iceland was able to conduct business with countries outside the Danish kingdom. This development was in line with the spread of liberalism in Europe. 


\section{STJÓRNMÁL \& \\ STJÓRNSÝSLA}

From the 1860s, the increased capital that found its way into the Icelandic economy through the sale of livestock to Britain and work provided by Faroese fishermen and Norwegians on the island served to modernise the economy. For instance, from 1876 onwards, the sale of sheep started to give generous returns and for the two decades that followed it became an important source of revenue for Icelandic farmers; between 1885 and 1895 it accounted for around 15 per cent of all exports from Iceland (Karlsson 2009, 40-44; Blöndal 1982). The Danish government helped to keep the export line open by having the British government overturn its ban on the import of Icelandic sheep in 1882. However, in 1896 the ban was put in place again and the sale of sheep to Britain was, for the most part, stopped (Karlsson 2009, 42). This new business opportunity had important effects not only for Icelandic farmers but also for the community at large. For instance, farmers founded their own cooperative movements and started to trade directly with Britain, instead of relying on the Danish merchants, whose prices were 30-40 per cent higher, for their imports (Júlíusson \& Ísberg 2005, 264-265; Karlsson 2000, 243-247).

Furthermore, fishermen from the Faroe Islands provided Icelanders with much better boats than they built themselves (Júlíusson \& Ísberg 2005, 262-263) and the Norwegian whaling and herring industrial bases were probably the most technologically advanced workplaces on the island. Hence, Icelanders' closest eastern neighbours provided an important backup in what was to become Iceland's most important industry. Also, in around 1880, greater market access for saltfish on European markets allowed Icelanders to buy more ships. They managed to acquire a substantial fleet of decked fishing vessels which were used for catching cod (Kjartansson 2010[2002], 38-39).

However, more was needed to modernise the economy and in 1886 the first Icelandic bank, Landsbanki Íslands, was established. However, it did not have much capital to loan out; most of its loans were to farmers and low-risk ventures and soon the credit that the bank could provide was considered to be insufficient for the economy (Karlsson $2000,289)$. Discussion arose on the need to have more foreign capital come into the country and in 1904 Íslandsbanki was established, with capital coming from Norway and Denmark. This was to become the main source of venture capital in the Icelandic economy and the supply of loan capital increased dramatically (Kjartansson 2010[2002], 29). This was the prerequisite for the growth in the Icelandic fishing industry in the beginning of the $20^{\text {th }}$ century.

With the establishment of Landsbanki, an Icelandic currency was also created and the state put bills in circulation. The amount was kept moderate to ensure it would maintain its value (Karlsson 2009, 58). Currencies were generally redeemable in gold at this time, but this new currency was formally not, and was rather seen as an extension of the Danish krone, and seen as an equivalent of that currency. When Íslandsbanki was established it was also given the right to issue Icelandic crowns (krónur) that were redeemable in gold. The introduction of this capital into the Icelandic economy was important for the economic development of the country. Banknotes replaced barter as 
the main means of conducting business. Loan capital was now available for prosperous business opportunities that had lain dormant for years. The currency benefited from its relations with the Nordic currency union that existed at the time and was in reality seen a part of the Danish monetary system. This gave the Icelandic economy a certain amount of credibility, ensured that prices and exchange rates remained stable and secured unhindered business transactions with other countries (Nordal 1998). Iceland thus benefited immensely from being part of the Nordic monetary union.

The Great War led to the collapse of the monetary system, based on a gold standard, that had been in place since the 1870s and as a result the monetary policies of almost all European countries were in disorder. The Icelandic króna lost half its value and price levels in Iceland rose dramatically during the war (Helgason 2002, 83). Iceland persisted in maintaining the equal exchange rate with the Danish krone, which was, however, no longer viable. In 1922 it was forced to devalue the króna by 23 per cent against the Danish krone. This marks the start of an independent monetary policy in Iceland and was only the first of many devaluations of the króna.

The Icelandic króna continued to depreciate against other currencies in 1923 and 1924. The Danish krone was no longer the main currency used by Icelanders in their foreign trade. This role had been taken over by the British pound. In 1925 - after a short period of a floating exchange rate - Icelanders decided to seek shelter for their currency by pegging the Icelandic króna to the British pound, an arrangement which would last for 14 years (the longest period of monetary stability in Iceland's history; Nordal 2002). The pound had been the principal currency of the gold standard, but was losing its stability and in 1931 Britain abandoned the gold standard and the pound was devalued. The peg of the Icelandic króna, and other Nordic currencies, to the pound was maintained through all this, so the value of the Icelandic króna fluctuated in the same manner as the pound. In 1939, the peg of the króna to the pound was abandoned and the króna was devalued again - this time by 18 per cent. Later the same year, a shelter for the currency was sought again, this time by pegging the króna to the US dollar, and this was maintained until 1949. The Icelandic króna has a history of constant devaluations and has depreciated by 99.95 per cent compared to the Danish krone since 1939 (Gylfason 2009).

Foreign capital and Danish grants, subsidies and technology opened the way to advancement in Icelandic society at the turn of the century. For instance, this was the case of the project to bring telegraph technology to Iceland. The introduction of the telegraph to the peripheral community in Iceland was immensely important. Messages that previously had taken up to three weeks to reach their destination in Europe could now be sent in a matter of minutes. This was important for merchants, who were now able monitor prices on the Continent more easily and make offers and payments through the banks, by telegraph (Kjartansson 2010[2002], 29-33).

This project was soon followed by other projects which were all more or less supported by the Danish government with loans from Danish banks and carried out by Danish firms. For instance, this was the case of the project to improve the water supply 
in Reykjavik by constructing waterworks for the town; they cost almost four times the annual revenues of Reykjavik. In 1911, a Danish bank provided a loan and a Danish firm provided the know-how and the equipment needed to carry out a construction of a harbour in Reykjavik - the main trading post on the island. Prior to this, ships had been forced to cast anchor outside Reykjavik and transport their goods ashore in smaller boats or on rafts. The harbour made an immense difference when it opened in 1917 (Friðriksson \& Dór 2013, 176-180).

Danish banks were willing to provide the Icelandic state with capital for these projects - loans at reasonable rates that had 40-50 year maturities. Without these funds, Iceland would not have been able to take on projects of this magnitude. In line with shelter theory, this access to foreign capital from Danish banks can be seen as help from an external financial authority that allowed Iceland to undertake necessary projects for the further development of its economy.

The Icelandic economy was in an upswing at the beginning of the $20^{\text {th }}$ century. Fishing had taken over as the most important industry in the country and new technology had modernised the country and moved it closer to its trading partners. This was largely due to the liberal policies that had prevailed in the world economy in the $19^{\text {th }}$ century and up until the First World War (see, for example, O’Brien \& Williams 2007).

The First World War changed the nature of the international economy and had an immense impact on the Icelandic economy. Denmark was neutral in the war; however, Britain wanted to close off the possibility of necessities being sold from Denmark to Germany and thus placed an embargo on shipments going to Denmark (Kjartansson 2010[2002], 54-55). It also took measures to stop exports of herring from Iceland to Norway as it feared it would be transported there from to Germany, via Denmark or Sweden (Jensdóttir 1980). In 1914, around 40 per cent of Iceland's exports were to Denmark, and 40 per cent of its imports were from that country, so the impact of this embargo was devastating for the Icelandic economy (Karlsson 2009, 294). This clearly indicates the importance of a cost-benefit analysis of the relationship between protectorates and dependencies.

In 1916, Iceland made a trade agreement with Britain concerning the import of fish and other Icelandic products to Britain, which saw this deal as an instrument in securing access to fish for itself while also limiting the supply for the opposing camp. Under the agreement, Britain committed itself to buying all the main Icelandic export products at a fixed price and to ensure the export of coal, salt and other necessities to Iceland (Jensdóttir 1980). The Icelandic government handled the negotiations and signing of this trade agreement itself, as the British government felt that Denmark, which formally was in charge of foreign affairs, was not in a position to do so (Karlsson 2009, 291-294).

As in the Napoleonic wars 100 years earlier, Britain decided to provide Iceland with economic shelter during wartime that would allow Iceland to continue selling its exports while markets on the Continent were closed and, more importantly, it provided Iceland with essential imports during this time. On neither occasion did Britain show any effort to maintain these economic relations after the wars had ended or to assert its power over 
Iceland and make them more permanent. It is thus apparent that clear incentives are needed in order for large entities to be willing to provide shelter for small states/entities in the international system.

The Danish and Icelandic markets were one and the same, as there were no tariffs in place between them up until 1918. Accordingly, Iceland, as part of the Danish kingdom, had tariff-free access to a larger market and, in that respect, received shelter from the Danish market. However, this was not the most suitable market for Iceland's export products. After the First World War, Danish shelter no longer took the form of an entrepôt for Icelandic exports on their way to their final destinations or providing access to its domestic market for Icelandic products. At the end of the war in 1918, Iceland had greatly reduced its exports to Denmark, the proportion having fallen to 27 per cent of total exports from Iceland (Karlsson 2009, 294). Nonetheless, Denmark was still an integral part of Iceland's trade policy and provided Iceland with essential assistance. The connection with Denmark helped in obtaining access for Icelandic exports, as Denmark handled Iceland's foreign affairs and thus made trade agreements on its behalf (see, for example, Thorsteinsson 1992,101-114). In the period 1921-1930, around 50 per cent of Iceland's exports went to Southern Europe (Magnússon 1993, 134-135). The closing of the Spanish market in 1936, because of the civil war, resulted in greater diversification of export markets; in 1938, 9 per cent of Iceland's exports went to the USA, 16 per cent to Germany and 21 per cent to Britain (Björnsson 1952, 225); in 1939, 10 per cent went to Denmark. Hence, Denmark continued to provide Iceland with essential economic shelter by providing access to other markets.

\section{Political shelter}

This section will focus on a number of aspects of political relations between Denmark and Britain, on the one hand, and Iceland, on the other, in order to analyse whether the case of Iceland supports the shelter theory's claim that a small state/entity needs military and diplomatic backing from a larger state or states in order to prosper. Until the Act of Union in 1918 Iceland had been a part of Denmark's foreign and security policy and could not hold an independent position in these matters. However, Icelanders were always in considerable contact with non-Danes, despite disapproval from the Danish authorities. In the period under study, Britain had emerged as a superpower and the North Atlantic was within its sphere of influence, which resulted in increased contacts between Iceland and Britain.

Iceland proclaimed its perpetual neutrality in Article 19 of the Act of Union. Denmark took on the responsibility of announcing this position of Iceland to other nations. This declaration was in reality an extension of the neutrality policy that the Scandinavian countries had pursued for decades and had served them well in the First World War (Jónsson 1989, 209). Apart from that, Iceland's capabilities were very weak; the country had a tiny population and also lacked the financial means to establish its own defences. Historically, Iceland had never taken any part in its own defences and always relied on Danish support and the peripheral position of the country in these matters. 


\section{STJÓRNMÁL \& \\ STJÓRNSÝSLA}

Initially, there were no international agreements that set out the rights and duties of neutral countries in war and regulated their relations with warring countries. However, in 1856, an agreement that stated the rights and obligations of neutral states in war was signed (Holbraad 1991). Neutrality had become a legitimate and realistic policy to pursue and small states, such as Denmark, that lacked the capabilities to take part in the power-play between the larger European states, saw it as their best option to survive in this system. By declaring neutrality, Iceland was, in a sense, relying on other states to respect the norms regarding neutrality and resist attacking a small and defenceless state, such as Iceland. These - alongside the peripheral position of the country - were the best defensive options for the country at this time.

After the Napoleonic Wars, the Danish kingdom was bankrupt and defenceless. Its capabilities to maintain control over its dependencies in the North Atlantic were seriously weakened. The North Atlantic was now de facto under Britain's dominance (Dorsteinsson 1976, 144). However, Britain had little interest in annexing Iceland, until the Second World War. It was considered too costly to maintain a permanent presence in the country and also unnecessary as the country was already within Britain's sphere of influence and Britain could in reality act as it wished in relation to Iceland (Agnarsdóttir 1993, 176-178). In a sense, Iceland continued to be a Danish dependency after the Napoleonic wars because Britain approved of that arrangement. Some historians have argued that Britain did not want Sweden to acquire the North Atlantic dependencies Iceland, the Faroe Islands and Greenland - after the war and thus included an article in the Treaty of Kiel securing Danish control over the North Atlantic dependencies (Gad 1979; Agnarsdóttir 1989; Porsteinsson \& Jónsson 1991). Others argue that Sweden did not request these islands since it did not have any interesting in them (e.g. Feldbæk 1998). Britain was the guarantor of Iceland's neutrality both in the Napoleonic wars and in the First World War and to the extent that Iceland had shelter in wartime, it came from Britain, not from Denmark. Any plans by foreign powers to increase their influence in Iceland or any effort to take over the island had to take into account the British response to such a move (Helgason 2008, 113). In that respect, Iceland found shelter in Britain's sphere of influence, especially in the latter part of the period when Iceland's peripheral geographical position did not provide the same buffer against foreign powers as it had done in previous centuries.

In 1938, the Nordic states reiterated their neutrality and signed a set of neutrality rules in an attempt to avoid involvement in a new major European war (Scott 1950, 282). On the other hand, it became evident in the Second World War that the neutrality of the Nordic countries was no longer respected by the European powers and both Denmark and Iceland were occupied by foreign powers. Britain invaded Iceland as soon as it though it was of importance for it during a time of war. The norms and rules of neutrality no longer prevailed for the Nordic states. Iceland's neutrality policy had failed to protect the country. However, it can comfortably be argued that Britain sheltered Iceland from Nazi occupation.

The Danish kingdom did not spend much effort providing Iceland with defences 
throughout our period. The only defence expense for Denmark in relation to Iceland was that each summer a ship was sent to Iceland as a coastal guard (Karlsson 2008, 280). Historically, European nations had exploited the rich fishing grounds surrounding Iceland. Denmark tried to the best of its ability to guard Iceland's territorial waters from foreign fishermen. However, this proved to be immensely difficult and it became evident that Denmark lacked the capability to provide Iceland with the military or diplomatic backing that the country sought - despite good intentions. Denmark did not possess the political power - military or diplomatic - to persuade other nations to respect Iceland's claims to its territorial waters.

Foreigners had for centuries been prohibited from fishing in Icelandic waters. In the monopoly trade era, this was mainly done in order to protect the commercial interests of Danish merchants, and the trading system. However, the ban was extended when the trade monopoly ended and it was stated that 'no foreigner was allowed to fish in Icelandic waters' (Thorsteinsson 1992, 38). At this point the territorial waters were considered to extend 16 nautical miles from land (ibid.). As the $19^{\text {th }}$ century progressed the number of foreign ships fishing in Icelandic waters increased and their operators refused to accept the 16-nautical-mile territorial limit and the closing of fjords and harbours in Iceland. Larger European powers pressured the Danish government into making concessions in these matters. Due to its inability to patrol the 16-mile Icelandic limit, the Danish government reduced the territorial waters down to 4 nautical miles in 1859, hoping that this would be respected by foreign fishing vessels. It also started to show more force in its efforts to defend the fishing grounds from vessels that did not abide by the rules, and numerous British vessels were confiscated and their operators fined for breaching the territorial limit (Dór 1982). Nonetheless, the British government continued to pressure the Danish government to concede further reductions of territorial waters and to give British fishermen docking rights in Icelandic ports. Eventually, in 1901, an agreement was signed between the Danish and British governments by which the limit of Iceland's territorial waters was set at 3 nautical miles, as the British government had insisted on for years, but fjords and bays were to be partially closed to British vessels (Thorsteinsson 1992, 37-51). Foreign fishing grew considerably in the wake of this agreement, to the Icelanders' dismay. In the period 1919-1938, Icelanders took only roughly one-third of the demersal fish catches in the waters off Iceland. The Icelandic fishing grounds were important to the British, as is shown by the fact that the total British catches in the Icelandic grounds during the 1919-1938 period were more than twice the total catch made by the British distant-water fleet on all the other fishing grounds combined (Dór 1995, 56-107).

Britain's determination in pursuing increased access to Icelandic fishing grounds shows that being in such close proximity to the empire brought not only benefits: there were also costs and one of them was the British demand to have access to the rich fishing grounds surrounding Iceland. Denmark lacked the capacity to protect Icelandic waters and this dispute shows that Iceland was clearly within Britain's sphere of influence and that the Danish government had little choice but to meet its demands. 


\section{STJÓRNMÁL \& \\ STJÓRNSÝSLA}

With the agreement of 1901, Britain had secured more or less what it always sought concerning access to Icelandic fishing grounds. The agreement was in place for the next 50 years and has, in Icelandic historiography, often been considered as an illustration of Denmark's indifference in defending Iceland's interests (Porsteinsson \& Jónsson 1991, 310; Thorsteinsson 1992, 50). However, it is perhaps more an illustration of the asymmetry in power between Britain and Denmark at this point. Denmark was unable to provide its dependency with shelter and, accordingly, protected its own interests.

The Act of Union of 1918 granted Iceland full autonomy in its foreign affairs. However, the countries agreed that Denmark should handle Iceland's foreign affairs and, thus, spare Iceland the great expense of running its own foreign service. Iceland was in a position to run an independent foreign policy if it wished to do so, and for the most part it did. Its administration was weak and in that respect it was highly influenced by Danish foreign policy. However, the Act of Union stated that Iceland could send out its own envoy on missions that were especially important for Iceland, if it wished, and was only asked to notify the Danish foreign minister if this were the case. Such an envoy would have to be funded by Iceland. Thus, Iceland could at any time implement its own foreign policy and could take part on an ad hoc basis in matters that were important for the country. Iceland was bound by all prior agreements that had been made by Denmark and concerned Iceland. However, after the validation of the Act of Union, international agreements made by Denmark would not take effect in Iceland unless they were also signed by the Icelandic government.

In the 1920 s and the 1930 s, trade agreements between countries became increasingly important in order to limit the effects of tariffs and other barriers to foreign trade. Hence, Iceland made numerous trade agreements in the years between the wars, 'mostfavoured-nation' agreements under which the countries in question agreed that they would always enjoy the best terms of trade that were being offered by the other at any given time. Usually it was the Danish government that decided to make a trade agreement with another country and then it would offer Iceland to join in on the agreement, or Denmark would make a separate agreement on Iceland's behalf (Thorsteinsson 1992, 101). It is safe to assume that, through its connection with the Danish kingdom, Iceland was able to make numerous favourable trade agreements that it otherwise would most likely not have been able to make.

Tariffs were not the only barrier to trade in the inter-war period. In the 1930s, countries increasingly demanded a system of equal exchange in foreign trade, with the aim that there would be a balance of trade between trading partners. Thus, if Iceland wanted to export products to a given market it was obliged, according to this system, to import products for the same amount from that country. The trade agreements had clauses that stated the quantity of a given product that could be imported/exported. This was potentially problematic for Iceland, which exported a large proportion of its products to markets in Southern Europe while its imports came from other markets, such as Scandinavia, Britain and Germany. In this situation it was highly beneficial for Iceland to be able to be a part of Denmark's trade agreements. Iceland's exports were 
considered to be a part of Denmark's and it was thus Denmark's equal exchange account that balanced the trade. For example, this was the case with the trade negotiations between Denmark and Italy in 1938-1940. Iceland was allowed to export fish to Italy for a certain amount that would constitute part of Denmark's equal-exchange account and balanced through Denmark's trade with Italy (Thorsteinsson 1992, 110). Denmark also agreed to increase its imports from certain countries in order for Iceland to be able to export fish to those countries. This was the case with Poland: Denmark agreed to increase its imports of Polish coal so that Poland would agree on a trade deal with Iceland. These agreements were negotiated by Denmark and they show the importance for Iceland of access to the Danish Foreign Service.

Finally, Iceland's capacity to handle its own foreign affairs grew steadily in the interwar period. The first Icelandic embassy was established in Copenhagen in 1920 as part of the Act of Union. Iceland had trade consultants who had the position of attachés in some Danish embassies in Europe, with diplomatic status and facilities within the Danish embassies (Thorsteinsson 1992). In 1930 - when Iceland celebrated the $1000^{\text {th }}$ anniversary of the establishment of its parliament, the Althingi - there was discussion of whether Iceland should join the League of Nations, and thus take on a more active role in foreign policy as a sovereign state. However, a majority of parliamentarians felt that Iceland's declaration of perpetual neutrality was sufficient and that membership of the LN was redundant in that light (Porsteinsson \& Jónsson 2001, 366). The feeling was that Denmark would look after Iceland's interests at the LN - as well as in other fields concerning foreign policy - and that membership would be too costly; that Iceland lacked the human resources and expertise needed for membership; and that Iceland would have no political gains from such a move (Valdimarsson 1993). Thus, Iceland continued, consciously, to rely on Denmark - and the shelter it provided - in many areas of its foreign policy. Denmark was in a way a 'guardian' of Iceland's foreign policy. However, after the German invasion of Denmark in 1940, Iceland took full control of its foreign policy since its relations with Copenhagen had been severed.

\section{Societal shelter}

In 1815, as soon as the Napoleonic Wars ended, relations between Iceland and Denmark were re-established and Copenhagen's place as Iceland's cultural capital reached new heights. New communications and transportation technology made the transfer of messages, norms, lifestyles and ideologies much easier and transformed centre-periphery relations.

Iceland's relations with the outside world were channelled through Copenhagen and became, in the era of monopoly trade, increasingly one-dimensional (Thorhallsson \& Joensen 2014). Contact maintained by Danish merchants became almost the sole channel of passenger transport and postal communications, as Iceland had no independent fleet or separate guarantee of services of any kind. The Danish kingdom established regular postal shipments between Denmark and Iceland after the trade monopoly was abolished in 1787. However, this did not improve the situation much for Iceland: services were 


\section{STJÓRNMÁL $\&$ \\ STJÓRNSÝSLA}

sparse, the ships were ill-suited for passengers, and the kingdom chartered them from merchants who often refused to transport the goods that Icelanders wanted to ship between the countries. On the other hand, there was one change that the Danish packet ships brought in the beginning: unlike the merchant ships, the packet ships sailed to Iceland in the autumn and back to Denmark in the spring. Thus, news could arrive from the Continent in autumn, and not only in spring, as had previously been the case. In 1839, a group of merchants and Icelandic officials bought their own ship, with the support from the Danish government, which wanted Icelanders to become more selfsufficient. This was the first time since the Middle Ages that Icelanders themselves owned a ship that could sail to the Continent (Friðriksson \& Pór 2013, 25).

On the other hand, it was not until 1852 that scheduled sailings between Iceland and the rest of Europe became more frequent, rising to four times a year - one of them to Liverpool, which created new opportunities for Icelanders to access the British market. Then in 1858 a steamship, the Victor Emanuel, started to sail to Iceland. It was larger and safer than the old schooners and could sail to Iceland all year round. This had immense impact on Icelandic society; the country was now in more or less constant contact with the outside world. It received news from the Continent more frequently and steamships were also used to transport goods for merchants, who were thus no longer forced to buy large quantities of goods and store them over the winter, but could buy according to demand. This allowed them to increase the variety of products on sale and made the running of businesses in Iceland much more efficient (Friðriksson \& Pór 2013, 30-38).

These efforts to increase transportation to Iceland and improve the island's communications with the outside world were all supported by the Danish government in one way or another. The government subsidised these efforts and rented ships from Danish businessmen which were used for the services to Iceland. On other occasions, the government provided military ships that maintained communications with Iceland, transporting people, goods and mail. According to the Status Act (stödulög) of 1871, postal services were to become a domestic matter that Iceland should pay for from its own budget. However, an exemption was made and Denmark continued to finance the postal transport between the countries (Friðriksson \& Pór 2013, 43).

Increased frequency of shipping to Iceland was essential for the small villages that were emerging on the coast and kept them in contact with the European continent and the British Isles in the $19^{\text {th }}$ century. At the turn of the century, more companies started to sail to Iceland and there was some competition between them. These companies also sailed to other harbours, thus introducing more variety into Iceland's foreign contacts (Friðriksson \& Pór 2013, 44-45). These communications, alongside new technology, such as the telephone, enabled Icelanders for the first time to follow current events in their neighbouring states, as has been discussed in previous sections.

After the Napoleonic Wars, almost all new agricultural technology and knowledge introduced in Iceland can be traced directly to the efforts made by the Danish government to modernise Iceland's agriculture. In 1817, the Royal Danish Agricultural Society (det Kongelige Danske Landhusholdningsselskab) offered young Icelandic farmers grants 
to study in Denmark for three years and learn the agricultural methods used there. In the coming decades, farmers would go to Denmark with the support of the Danish government to learn new methods in agricultural production which they taught to their countrymen. In the 1830 s the first Icelandic veterinarian received his licence in Denmark. Also, Icelandic women travelled to Denmark to learn about the production of dairy products and new methods in the handling of milk (Friðriksson \& Dór 2013, 410-411).

In the latter half of the century, the Danish government continued to support Icelandic agriculture and even supported farmers to study agronomy in Norway and Scotland. For example, the Royal Danish Agricultural Society awarded scholarships to Icelanders, supported Icelandic and Danish experts who travelled around the country to teach new techniques and methods in agriculture; it sent seeds and plants, gave farmers new tools, sent new domestic animals to Iceland, such as pigs, in an effort to increase the variety in animal farming and sent experts to oversee, for instance, irrigation projects (Friðriksson \& Pór 2013, 410-415). On other fronts, agricultural schools were established on the Danish model; the introduction of dairy farms at the turn of the century followed in the footsteps of developments in Danish agriculture and the knowledge acquired there in the latter half of the $19^{\text {th }}$ century; slaughterhouses were established on the Danish model and the butchers learned their trade in Denmark and, lastly, the Danish government also supported soil reclamation and reforestation projects in Iceland (Friðriksson \& Dór 2013, 415-428).

In the $19^{\text {th }}$ century, the improvements that were made in the health-care system in Iceland came from Denmark. These efforts were supported and paid for by Denmark. Most doctors in Iceland received their diplomas at the University of Copenhagen - a leading university in Europe - but not many persons pursued this career due to low pay and immense workloads. In 1862, the Director of Health (landlaknir) re-established a domestic school in medicine, to address the growing demand for doctors, and 13 students qualified from it in about 15 years (Karlsson 2008, 230). In 1802, vaccination was tried for the first time in Iceland. Cows were used to produce the serum that was then used in vaccination for humans. This innovation entered Iceland through Denmark and in 1811 an Act was passed in Denmark - which was applicable to Iceland - that made it mandatory for the government to provide vaccination for smallpox to the general public (Jóhannesson 1950, 182). Smallpox epidemics - which historically had ravaged the country - were no longer the same threat.

In 1847, a Danish doctor was sent to Vestmannaeyjar to deal with the high infant mortality in the islands (see Garðarsdóttir 2002, 108-121). He managed to reduce the mortality rate from 74 per cent in the period from 1827-1847 to 25 per cent by introducing disinfection and hygiene in connection with childbirth (Júlíusson \& Ísberg 2005, 300-301). In the middle of the century, transfer of knowledge from Denmark lowered the infant mortality rate in the country when doctors started to encourage women to breastfeed their new-borns. Furthermore, the state had, since 1760, supported the education of midwives in Iceland. Alongside the creation of the post of Director 


\section{STJÓRNMÁL \& \\ STJÓRNSÝSLA}

of Health, a school of midwifery was established (Friðriksson \& Pór 2013, 169). The Danish government not only paid for the education of midwives, but also their salaries after their studies, as it did with other officials in Iceland.

In 1898, the Oddfellow society in Denmark paid for and built a new leprosy hospital in Iceland which would serve until the 1940s, at which time leprosy had more or less been exterminated in the country. In 1895, missionaries of the St. Josef rule came to Iceland from Denmark and started to practice home nursing and poor relief in Reykjavík. In 1901 they started work on a hospital in Reykjavik which would serve as the country's main hospital until the 1930s when the National Hospital was built. The Icelandic state thus managed to avoid using its own funds for building a hospital until the 1930s. A few small private hospitals had been built in the $19^{\text {th }}$ century but these large hospitals were built with foreign funds and foreign knowledge for the benefit of the general public in Iceland (Ísberg 2005; Friðriksson \& Pór 2013, 163-168).

The University of Copenhagen was Iceland's institute for higher education and there was a dramatic increase in the number of students travelling to Copenhagen in our period. In the $19^{\text {th }}$ century, 435 Icelanders studied at the university (the number rose steadily until 1918) compared with around 500 Icelanders from 1550 to 1800 (Friðriksson \& Pór 2013). All these students benefited from the free board and lodging offered by the Danish government from 1579 to 1918.

Also, many Icelanders travelled to Copenhagen to learn various crafts, including carpentry, photography, machine construction, tailoring, blacksmithing, printing, painting, gold- and silversmithing, watchmaking and shoemaking. Skills in these trades were important for the further development of the society and an integral part of its move towards modernity. There are records of 680 Icelandic craftsmen travelling to Copenhagen to study in the years 1815-1915 - but this probably understates the true number (Friðriksson \& Pór 2013, 306). Also, numerous Danish craftsmen travelled to Iceland to teach the local population new trades. Copenhagen was Iceland's window to the world of new crafts and trades and it actively promoted these skills to Icelanders. As a result, Danish influences could be seen in all areas of Icelandic society, whether it was in house-building, machine skills, bakeries or barbershops, the knowledge and influences came from Denmark.

Iceland, like other countries, was affected by international ideological currents in the period under study. Many international ideologies entered Iceland in the period, mostly through Denmark, and influenced Icelandic society. This was for example the case with romanticism, liberalism, nationalism, religious movements, temperance societies, organized youth societies, women's rights movements, socialism and cooperative societies. Iceland developed at a slower pace than most other European entities in this period and as a result many of the ideas promoted by the Enlightenment - such as education for the general public, industrial progress, humanitarianism, and belief in the human spirit and technology - were still applicable in $19^{\text {th }}$-century Iceland and affected how other ideological currents were received in the country (Sigurðsson 2006).

Furthermore, women's rights entered Iceland through Denmark. The Danish 
administration regularly sent recommendations to Iceland about what Acts regarding women's rights had been passed and how they should be implemented on the island. The Icelandic women's rights movement benefitted from the strength of the Danish movement. The model for women's schools came from Denmark and was funded by Danish private organizations and individuals (despite considerable opposition to such schools in Iceland; Friðriksson \& Pór 2013, 397). In the 1890s, left-wing and liberal political views that emphasised women's rights started to gain a foothold in Iceland. In 1915, women over the age of 40 were given suffrage. By 1921, a constitutional amendment had given all women and workers suffrage at the age of 25 . This appears to have been in line with a demand made by the Danish government in the negotiations leading to the Act of Union in 1918 (Styrkársdóttir 1994).

Romanticism was at its height in the first half of the $19^{\text {th }}$ century and as a result there was greater interest in the Nordic cultural heritage within the Danish kingdom. Copenhagen became, to an even larger degree than before, the place where the Icelandic cultural heritage was preserved. The state and private individuals sponsored research in the field and Icelandic students in Copenhagen were hired to read and transcribe old manuscripts. Also, the state supported the publication of Icelandic literature and actively sought to promote Icelandic culture as the shared Nordic cultural heritage (Friðriksson \& Dór 2013). All this was very important for the preservation of Iceland's language and medieval literature, and the development of national identity in Iceland. For example, this attitude towards Iceland can be seen in the fact that Denmark never tried to force Icelanders to use Danish as their administrative or clerical language. Hence, Agnarsdóttir (2008) and Karlsson (2008, 280-285) argue that Icelandic language and culture was considered to be a great asset for the Danish kingdom which overshadowed the fact that the island did not return material profit for the kingdom.

From around 1830 and onwards, the Romantic ideology in Europe took on a more political form, as nationalism became more visible in public discourse. Furthermore, in this period, liberalism developed further the ideas expressed by the Enlightenment and together these ideas would have an immense impact on the development of European, as well as Icelandic, society. Iceland's move towards greater autonomy can be directly linked to the political developments taking place in Europe and within the Danish kingdom at the time (Karlsson 2000, 200-204).

In the 19th century, liberalism never gained the same foothold in Iceland as it did in Denmark, though it became an integral part of the independence discourse. In 1849, a new constitution was introduced in Denmark that gave Danish citizens extensive rights that they had previously not exercised. Due to disputes regarding the legal status of Iceland within the Danish kingdom, this constitution did not immediately apply to Iceland. Thus there was no human rights legislation in Iceland until 1874 - when Iceland received its constitution from the King. Some of the rights introduced in the Danish constitution were taken up ad hoc into Icelandic legislation in the meantime (Karlsson 2008, 247).

The ruling elite in Iceland opposed many of the civic rights that were an integral 


\section{STJÓRNMÁL \& \\ STJÓRNSÝSLA}

part of the liberal modernisation that was taking place in Europe in the $19^{\text {th }}$ century. For instance, it opposed allowing more freedom for working people in choosing where they lived, having the right to establish homes and freedom in marital issues, as it feared this would undermine its strong and dominant position in the society. Hálfdanarson (2007, 45-76) argues that Icelandic farmers (landowners) supported the independence struggle because they feared the diffusion of liberal ideas from Denmark and wanted to protect the conservative societal structure on which their power was based. The pursuit of greater national autonomy and independence was therefore in one sense a means by which to forestall the liberalization of Iceland. The farmers managed to postpone many reforms that had been introduced elsewhere in the kingdom and, as a result, the general public did not have the same rights as existed in Iceland's neighbouring states at the end of the $19^{\text {th }}$ century.

\section{Conclusions}

Our findings indicate that Iceland relied on its larger neighbours for modernization and prosperity. Also, it was in need of political cover, in line with the shelter theory on the importance of military and diplomatic support and the significance of beneficial norms and rules of the international system for small entities. On the other hand, outside assistance did not come without cost: Danish economic cover was highly costly at the beginning of the period under study and Britain did more or less what it wanted in the North Atlantic, especially in times of political crisis in Europe. Our findings indicate that political shelter can be highly costly for a small entity/state. The shelter theory has to acknowledge these costs and take them into account in its cost-benefit analysis. Iceland was at the mercy of its larger neighbours, particularly when their political and economic interests were at stake. Accordingly, the paper also confirms the claim of the small-state literature that small states rely on their larger neighbour for survival.

Denmark's willingness to provide the island with essential financial backup was fundamental in the modernization of the society, providing the basis for economic improvements and enabling Iceland to manage itself in the early $20^{\text {th }}$ century. Iceland's economic development - despite late industrialization - would have been even slower without this initial start capital.

Societal relations with Copenhagen were of fundamental importance in the preservation and evolution of Icelandic culture and identity. These provided the foundation of the modern society and led to the establishment of the Icelandic state. Cultural relationships and transfer of norms and knowledge are seen as important in order to avoid isolation and seek acknowledgement though these relations, according to Rokkan and Urwin's theory on centre-periphery relationships in state-building in Western Europe. This illustrates the significance of being part of a wider societal community and its associated benefits.

Furthermore, Denmark provided important political shelter in terms of significant diplomatic support in guaranteeing trade agreements with other states until the countries' relations were severed in 1940. Iceland's strategy of relying on its former 
ruler, Denmark, to implement its foreign policy in the inter-war period was a forced choice necessitated by its limited administrative capacity and competence and economic resources. Moreover, Denmark led by example - confirming another typical claim of the literature on small states' relations with their larger neighbours. For instance, this was the case with Iceland's decision to follow other Nordic states' stance on neutrality. The Nordic states were not in a formal alliance but their common declaration of neutrality indicated a united front that was designed to strengthen their neutrality policy against potentially aggressive larger European neighbours. In declaring neutrality, Iceland sought cover in the prevailing norms of the international system available at the time to small and defenceless states. This - alongside the peripheral position of the country - were the best defensive options for the country at this time. Accordingly, Iceland's smallness played a crucial part in shaping its foreign policy strategy in the inter-war period.

Britain guaranteed Iceland's neutrality in the First World War, as it had done in the Napoleonic Wars, and its important connections with the outside world. Iceland could no longer seek security guarantees by allying itself with the other Nordic states. Denmark had long passed its hayday, and Norway had done so a few centuries earlier. Denmark had been downgraded to the status of a small European state and could not provide Iceland with political and economic cover in times of crisis. Iceland had for a considerable time been within the British sphere of influence. Britain provided the island with political and economic cover. Iceland's strategic geographical location had undergone fundamental changes. Iceland was as much in need as ever of secure shelter from a powerful international actor. It needed a reliable protector that would be able to reduce pre-crisis risk, assist with response in the event of crisis and then with recovery measures. At the end of our period under study, Iceland's reliance on Britain was more obvious than ever before.

Interestingly, Iceland's increased autonomy and full independence did not have any impact on its need for political, economic and societal shelter. Importantly, the rules and norms of the international system (in line with the shelter theory regarding political cover) in terms of respect for nations' autonomy were of fundamental importance in Iceland's quest for self-governance and, later, full independence. Iceland's larger neighbours accepted its quest for self-governance, with the legitimatization of the principle of national self-determination. However, Iceland's closest world power, Britain, did not hesitate to occupy the island when this suited its interests. Yet again, Iceland's smallness and its relations with its most powerful neighbour determined its destiny.

\section{References}

Agnarsdóttir, A. (1989). Great Britain and Iceland 1800-1820, PhD dissertation. London: London School of Economics and Political Science, Department of International History.

Agnarsdóttir, A. (1993). "Ísland á bresku áhrifasvæði fram að síðari heimsstyrjöld", in M. Snædal and T. Sigurðardóttir (eds.) Frandafundur: Fyrirlestrar frá islensk-fareyskeri rádstefnu i Reykejavík. 20.-21. ágúst 1992. Reykjavík: Háskóli Íslands - Háskólaútgáfan, 162-178.

Agnarsdóttir, A. (2008). 'The Danish Empire: The Special Case of Iceland', in M.N. Harris and C. Lévai (eds.) Europe and its Empires. Pisa: Plus-Pisa University Press, 59-84. 
Bailes, A.J.K. and Thorhallsson (Dórhallsson), B. (2013). "Instrumentalizing the European Union in Small State Strategy", Journal of European Integration 35(2), 99-115.

Bailes, A.J.K., Thorhallsson (Pórhallsson), B. and Johnstone, R. L. (2013). "Scotland as an Independent Small State: Where would it seek shelter?”, Stjórnmál og stjórnsýsla 9(1), 1-20.

Björnsson, Ó. (1952). Djódarbúskapur Íslendinga. Reykjavík: Hlaðbúð.

Blöndal, S. (1982). Sauðasalan til Bretlands. Reykjavík: Sagnfræðistofnun Háskóla Íslands.

Feldbæk, O. (1998). Danmark-Norge 1380-1814. Bind IV. Nærhed og adskillelse 1720-1814. Oslo: Universitetsforlaget.

Friðriksson, G. and Dór, J.P. (2013). Kaupmannaböfn sem böfuðborg Íslands. Síðara bindi. Reykjavík: Hið íslenska bókmenntafélag.

Gad, F. (1979). “"LLa grönlande, les isles de ferröe et l'islande non comprises” A new look at the origins of the addition to Article IV of the Treaty of Kiel of 1814", Scandinavian Journal of History 4, 187 205.

Garðarsdóttir, Ó. (2002). Saving the child: regional, cultural and social aspects of the infant mortality decline in Iceland, 1770-1920. Ph.D. dissertation from Umeå University: Umeå: Umeå University.

Gunnarsson, G. (1987). Upp er boðid Ísaland: Einokunarverslun og íslensket samfélag 1602-1787. [Reykjavík]: Bókaútgáfan Örn og Örlygur.

Gylfason, P. (2009). "Is Iceland too small", Vox, Voxeu.org. Available at www.voxeu.org/article/iceland-too-small (accessed 12 June 2014).

Hálfdanarson, G. (2007) Íslenska pjóđríkið: uppruni og endamörk, (2 ${ }^{\text {nd }}$ ed.). Reykjavík: Hið íslenska bókmenntafélag.

Helgason, M.S. (2002). “„Hin heiðarlega króna“"”, in Jónas H. Haralz (ed.) Frá kreppu til vidreisnar: Dattir um hagstjórn á Íslandi á árunum 1930 til 1960. Reykjavík: Hið íslenska bókmenntafélag, 81-134.

Helgason, D. (2008). “The Pen and the Borrowed Sword: 500 years of Icelandic defense policy", Scandinavian Journal of History 33(2), 105-121.

Holbraad, C. (1991). Danish neutrality: a study in the foreign policy of a small state. Oxford: Clarendon Press.

Jensdóttir, S.B. (1980). Ísland á brę̌ku valdsvađi 1914-1918. Reykjavík: Menningarsjóður.

Jóhannesson, G.Th. (2013). The bistory of Iceland. Santa Barbara, CA: Greenwood.

Jóhannesson, P. (1950). Saga Íslendinga. 7: Tímabilið 1770-1830: Upplýsingaöld. Reykjavík: Menntamálaráð og Pjóðvinafélag.

Jónsson, H. (1989). “Íslensk hlutleysisstefna: fræðilega hlutleysið 1918-1941”, Andvari 114(1), 203-224

Júlíusson, Á.D. and Ísberg, J.Ó. (eds.) (2005). Íslandssagan i máli og myndum. Reykjavík: Mál og menning.

Karlsson, G. (2000). The History of Iceland. Minneapolis: University of Minnesota Press.

Karlsson, G. (2008). "Upphafsskeið pjóðríkismyndunar 1830-1874", in S. Líndal and P.H. Árnason (eds.) Saga Íslands IX. Reykjavík: Hið íslenzka bókmenntafélag, 167-374.

Karlsson, G. (2009). "Atvinnubylting og ríkismyndun”, in S. Líndal and P.H. Árnason (eds.) Saga Íslands X. Reykjavík: Hið íslenzka bókmenntafélag, 5-312.

Katzenstein, P. (1984). Corporatism and Change: Austria, Switzerland, and the Politics of Industry. Ithaca and London: Cornell University Press.

Kjartansson, H.S. (2010 [2002]). Ísland á 20.öld. Reykjavík: Sögufélag.

Magnússon, G. (1992). Peningar og gengi: Greinasafn um hagstjórn og peningamál á Íslandi. Reykjavík: Hagfræðistofnun Háskóla Íslands.

Magnússon, M.S. (1993). "Efnahagspróun á Íslandi 1880-1990”, in G. Hálfdánarson and S. Kristjánsson (eds.) Íslenskepjóđfélagspróun 1880-1990: Ritgerơir. Reykjavík: Félagsvísindastofnun Háskóla Íslands and Sagnfræðistofnun Háskóla Íslands.

Nordal, J. (1998). "Efnahagslegt sjálfstæði Íslendinga: Nokkrir pættir hagstjórnar á fyrstu áratugum fullveldisins”, in G.J. Guðmundsson and E.K. Björnsson (eds.) Íslenska sögupingið 28.-31. maí 1997: Rádstefnurit I. Reykjavík: Sagnfræðistofnun Háskóla Íslands and Sagnfræðingafélag Íslands, 366-378.

Nordal, J. (2002). “Mótun peningakerfisins fyrir og eftir 1930”, in Jónas H. Haralz (ed.) Frá kreppu til vidreisnar: Dattir um bagstjórn á Íslandi á árunum 1930 til 1960. Reykjavík: Hið íslenska bókmenntafélag, 41-79. 
Nordal, J. and Tómasson, Ó. (1985). "Frá floti til flots", in Sigurður Snævarr (ed.) Klemensarbók. Reykjavík: FVH, 215-234.

O’Brien, R. and Williams, M. (2007). Global political economy: evolution and dynamics, (2 ${ }^{\text {nd }}$ ed.). Basingstoke: Palgrave Macmillan.

Rokkan, S. and Urwin D.W. (1983). Economy, Territory, Identity: Politics of West European Peripheries. London, USA, New Delhi: Sage Publications.

Sigurðsson, I. (2006). Erlendir straumar og islenæk viðhorf: ábrif fjölbjóðlegra bugmyndastefna á Íslendinga 1830_ 1918. Reykjavík: Háskólaútgáfan.

Scott, F.D. (1950). Scandinavia. Cambridge, MA: Harvard University Press.

Styrkársdóttir, A. (1994). Barátta um vald: Konur íbajarstjórn Reykjavíkur 1908-1922. Reykjavík: Háskólaútgáfan.

Thorsteinsson, P.J. (1992). Utanríkispjónusta Íslands og utanríkismál: sögulegt yfrlit 1. Reykjavik: Hið íslenska bókmenntafélag.

Valdimarson, V.U. (1993). Ísland i eldlínu alpjódamála: Stefnumótun og samvinna innan Sameinudu pjódanna 19461980. Reykjavík: Alpjóðamálastofnun Háskóla Íslands.

porsteinsson, B. (1976). Tíu porskastrí 1415 - 1976. Reykjavík: Sögufélagið.

porsteinsson, B. and Jónsson, B. (1991). Íslandssaga til okkear daga. Reykjavík: Sögufélag.

Dór, Jón P. (1982). Breskir togarar og Íslandsmið 1889-1916. Reykjavík: Bókmenntafélagið.

Dór, Jón P. (1995). British Trawlers and Iceland 1919-1976. Gothenburg: University of Gothenburg.

Dórhallsson (Thorhallsson), B. (2011). "Domestic buffer versus external shelter: viability of small states in the new globalised economy", European Political Science 10, 324-336.

Pórhallsson (Thorhallsson), B. (2012). "Iceland's external affairs in the Middle Ages: The shelter of Norwegian sea power", Stjórnmál og stjórnsísla 8(1), 5-37.

pórhallsson (Thorhallsson), B. and Joensen, T. (2014). "Iceland's External Affairs from 1550-1815: Danish societal and political cover concurrent with a highly costly economic policy", Stjornmál og stjórnsýsla 10(2), 191-216.

pórhallsson (Thorhallsson), B. and Kristinsson, D. (2013). "Iceland's External Affairs from 1400 to the Reformation: Anglo-German Economic and Societal Shelter in a Danish Political Vacuum", Stjórnmál og stjórnsýsla 9(1), 113-137. 